penned for the night in corrals. Only the sheep herders live much as they used to, but there is now only one where fifty years ago there were perhaps a hundred. However, in any attempt to find out if these foxes still persist in some remote corner, every cowboy, sheep-herder, and Indian should be asked for information. No Kit Foxes having been seen or shot for years alarms me, but does not prove that they no longer exist.

Editor's Note: A letter from Mr. S. A. Mann of Skull Creek tells how years ago kit foxes were very numerous and easy to trap or poison. He says that they were trusting animals and came in around the farm build. ings. He has not seen one since about 1905.

Mr. Don Kirk, P.F.R.A., Regina, is not so sure that the kit fox is extinct in Saskatchewan. He thinks he saw one last summer on the south watershed of the Cypress Hills near Cypress Lake. He wrote several letters to old timers in the area but they were guarded in their comments. Mr. T. E. Fordice says, "We have not seen any kit fox although they used to be here and it is rumoured that there are some near." Mr. H. I. Wallace says, "I believe one was seen near Battle Creek in 1954."

The last authentic report we have of a kit fox seen in Saskatchewan comes from the Museum's files. This was a kit fox trapped in 1927 near Ravenscrag and donated to the Museum where it has been mounted and preserved.

\title{
The Ups and Downs of Game at Crescent Lake
}

\section{By. K. E. BAINES}

The following observations are based on information taken from my grandfather's diary commenced in August 1883 and later from $m y$ father's diary commencing in 1917both of which are in my possession. Besides these, I have personal memories dating from about 1910 from my contacts with both the above men. The area concerned is in the immediate vicinity of Crescent Lake which is my birthplace and still very dear to me, even though I left it some twenty years ago. Crescent Lake is 16 miles south of Yorkton.

Crescent Lake is a shallow body of water which in dry cycles dries up to nothing but a meadow of grass and weeds. In 1883 it was full of water. It was completely dry about 1897 and again in 1938. It was full to overflowing in 1919 and is again high in 1956. The amount of water in the lake, of course, reflects the wet and dry cycles of the district and has a definite bearing on many species of game.

I will deal with game animals first. In 1883 the prairie was covered with buffalo bones, the last of these large animals having been disposed of only a few years before. Almost as conspicuous as the buffalo bones were the large antlers of elk, and I can still remember seeing lots of these in some of my hikes to the less-frequented spots. Elk must have been very numerous some years previous and they seem to have disappeared about the same time as the buffala. They were probably just an extension of the great foothill herds and for some unknown reason they retired to that area and to a few isolated spots such as the Moose Mountains and Beaver Hills, and have never been away from these places since to any extent. Man was surely not a factor here; otherwise, elk could never have made a comeback-even with protection.

Mule Deer or Blacktails, as they were locally known, were fairly common in 1883. They were the only deer. They became very scare and the season was closed about 1910. About this time Whitetail, or Virginia Deer, appeared in quantity and at practically the same time the Mule Deer became scarcer, disappearing altogether about 1928. The Whitetail became more common until there was insufficient pasture and many died during several springs in the 1920 's and even later. Again the Mule Deer came from the west and has withdrawn in that direction, while the Whitetail came from the east and appears to be pushing farther west.

Rabbits and Jackrabbits have had their usual ups and downs, but I am beginning to wonder just what is happening here, as they have not been numerous for ten or fifteen years now. Could the use of 2-4-D be having an adverse effect on the rabbit population?

Foxes were numerous in 1883, but coyotes did not appear for some years. When they did appear, the fox nearly disappeared and has 
never staged a comeback. Only rarely is a fox seen now. Coyotes have been common for fifty years. As for other animals, the advent of the white man does not seem to have had any particular effect.

Jackfish were available in Crescent Lake in 1883 and have reappeared during periods of high, water such as 1955 .

Game birds are a much larger subject. Sharp-tailed Grouse were mentioned by my grandfather in 1883 and they have practically held their own until very recently. Concentrated agriculture and much pasturing will probably eventually force this bird into the uninhabitable areas of Saskatchewan. The Pinnated Grouse appeared about 1900 and became just as plentiful as the Sharptail from 1910 to 1920 , when it gradually thinned out and disappeared. These were fine birds and just why they came and went has never been explained. They were fairly common as far north as the Arborfield district in 1920. They were more wary than Sharptails so gun pressure can hardly be blamed. Conditions were no different when they came than when they disappeared. They were apparently an extension from Minnesota and Wisconsin, and they have probably withdrawn to those states. Why?

The Mallard Duck has shown itself well able to look after itself with the help of good game management. Some other varieties of ducks may not be doing so well. I can remember seeing large flocks numbering hundreds of Gadwalls, and even Pintails, both of which could be classed as uncommon now. Teal and Shovellers are also less common.

The Canada Goose still nests in and around Crescent Lake as it has done for the past 70 years. The flocks that used to collect in late August and camp in certain favored locations around the lake for the night, are no more. This wily bird has learned that to survive he must bypass certain spots, and this is one of them.

The White-fronted Goose, the Wavey or Snow Goose, and various small subspecies of the Canada were common in large flocks in the early 1900 's, but by 1930 these too had commenced using other migration routes and they are rarely seen now.
The Whooping Crane always appeared in spring and occasionally one was shot, but very few have been seen since 1900. The Sandhill Crane used to nest in the area but this bird has also become uncommon and only passing flocks appear now.

No discussion on game birds would be complete without some mention of Crows and Magpies. Crows were very scarce in 1883 but gradually increased until about 1915 when they levelled off at about the same number Magpies were nonexistent until 1920 or later and were scarce until a few years ago. Now they are almost as numerous as Crows. Possibly this severe winter will thin them out some. Both these birds do eat large numbers of game birds' eggs and young and I am not defending them. Nevertheless, it seems difficult to account for any particular change in game bird population that will coincide with a similar change in numbers of these predators. My opinion, for what it is worth, is that game birds survive in relation to their habits of hiding their nests. Those which seek good cover continue to increase, and those which do not are gradually eliminated.

This same theory can be used when discussing gun pressure. The most sought-after game birds are Canada Geese and Mallard Ducks. Forty years ago Canada Geese came out to feed on grain fields in late August or early September. They always came to the same field and to the same spot until shot or disturbed in some other way. They fed regularly night and morning. Now they have changed their habits completely. They may or may not come to the same field; they feed at any time of day. Those which continued in the old habits have probably been shot while the ones capable of adapting themselves have become more numerous and consequently lead the flocks. Mallard Ducks are commencing more and more to feed on grass fields after dark, probably because ducks cannot be shot after dark.

It seems probable to me, therefore, that our game birds will find ways to survive in spite of increasing gun pressure and changes due to greater human populations in their old haunts. 